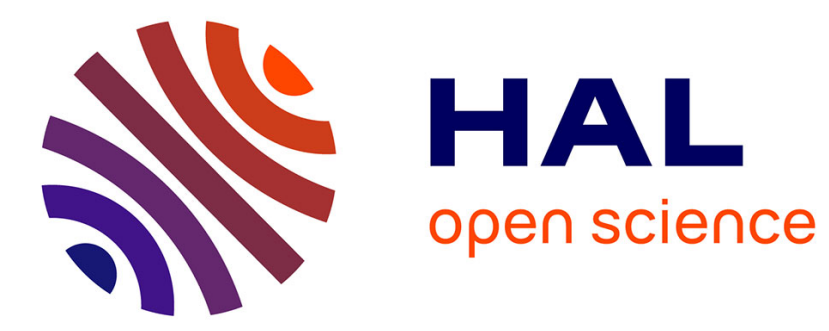

\title{
Introduction Forms and Norms: Questioning Illegal Urban Housing in the Middle East
}

\author{
Myriam Ababsa, Eric Denis, Baudouin Dupret
}

\section{To cite this version:}

Myriam Ababsa, Eric Denis, Baudouin Dupret. Introduction Forms and Norms: Questioning Illegal Urban Housing in the Middle East. Popular Housing and Urban Land Tenure in the Middle East: Case Studies from Egypt, Syria, Jordan, Lebanon, and Turkey, The American University in Cairo Press, 2012. halshs-01573824

\section{HAL Id: halshs-01573824 \\ https://shs.hal.science/halshs-01573824}

Submitted on 10 Aug 2017

HAL is a multi-disciplinary open access archive for the deposit and dissemination of scientific research documents, whether they are published or not. The documents may come from teaching and research institutions in France or abroad, or from public or private research centers.
L'archive ouverte pluridisciplinaire $\mathbf{H A L}$, est destinée au dépôt et à la diffusion de documents scientifiques de niveau recherche, publiés ou non, émanant des établissements d'enseignement et de recherche français ou étrangers, des laboratoires publics ou privés. 


\section{POPULAR HOUSING AND URBAN LAND TENURE IN THE MIDDLE EAST \\ Case Studies from Egypt, Syria, Jordan, Lebanon, and Turkey}

Edited by Myriam Ababsa, Baudouin Dupret, and Eric Denis

\section{INTRODUCTION \\ Forms and Norms: Questioning Illegal Urban Housing in the Middle East}

Myriam Ababsa

Eric Denis

Baudouin Dupret

This volume aims at taking seriously and at describing two major transformations observed within the Arab world: firstly, the accelerated mutation of public policies towards neighbourhoods characterized as irregular or illegal; secondly, the claim that this mode of housing in metropolises constitutes the ordinary and majority condition. There is nothing specific or original in this statement. To some extent, the goal is even to stress the contrary, i.e. to account for the banality of this type of urban condition in this part of the world, together with its evolution.

Bearing on original empirical work, our will to describe interactions specifically located within the urban space participates in a general trend to think afresh the proper ways to observe societies of the Arab world. Here, longer perhaps than anywhere else, the grid of analysis remained constrained by a dualistic way of thinking, opposing State apparatus to populations deprived of any capacity to grasp politics. The few works dealing with urban illegality in the Arab world underscored the lack of institutionalized forms of governance, contrary to South America and the Indian democracy where neighbourhood associations and non-governmental organisations are active in the protection of squatters' rights. ${ }^{1}$ However, several studies dealing with the strenuous avenues of political participation in Cairo (Singerman, 1996), on the street as the locus of popular micro-interventions and the quiet encroachment of the poor in the city of Teheran during the 1980s (Bayat, 1997), and on ordinary citizens' participation in the Arab world (Berry-Chikhaoui \& Deboulet, 2000) made it possible to break with this burdensome tradition. They all proposed relevant tracks for researching the urban space through the most ordinary interactions around which agreements - which here like elsewhere make the society - are built.

Without falling in the trap of radical readings which identified politics everywhere, in every single daily interaction (cf. Hoodfar, 1997) - something that contributed to denying any efficacy of "limited democracy" regimes in place, these approaches share a real heuristic force. They definitely permit to establish a continuum between different modes of action and to bind ordinary citizens, public agents and entrepreneurs in their daily interactions. Recent work in legal anthropology (cf. Dupret, 2006) testifies to the same: through daily practices within local tribunals, it shows how legal norms are produced and how the relationship with

\footnotetext{
${ }^{1}$ According to Nezzar Al Sayyed, urban informality in South America involves political belonging and sets a relationship of reciprocity between groups of squatters and the State, while in the Middle-East, on the contrary, the depoliticising of informality warrants the squatters' projects; whereas in South America, squats would develop or be boosted in contexts of political change - polls for instance - these changes would take place in the Middle-East during phases of economic change (Sayyed, 1993: 14).
} 
positive law in constructed. Observing most ordinary interactions and practices gives the means to renew the analysis of societies, e.g. urban communities for our present purpose. The precise description of interactions, routines and ordinary practices sheds light on the way in which "bits and pieces" of cities, neighbourhoods or broader urban formations appear, are reproduced, balance each other, evolve and transform.

It seems rather unproductive to continue thinking about changing urban environments exclusively in terms of social contradictions and deep inequalities. The latter are obvious and beyond contest, but their denunciation draws little analytical benefit. Exploring the ways in which agreements are reached and compromises emerge proves much more heuristic, even in a contest of steeply asymmetrical positions. It does not equate with an irenic vision of empirical realities; it aims at substituting for the logic of critique the care for descriptions of mechanisms ongoing in the deployment of urban phenomena.

Breaches do not exist but through the permanent crossing of institutionalized borders, blurring them and re-making continuums with the co-operation of State agents. As the anthropologist Frederik Barth puts it, border drawing is a collaborative or conflicting, thus social, accomplishment, the sides of the dividing line concurring in the definition of the "wherefrom I speak" which is necessary in interaction. This means that instead of dichotomies opposing permanence and change, public and private, State and society, it seems more fruitful to adopt an endogenous perspective which both objectifies these entities and actualizes practices reflecting an actual life which is far less contradictory and chaotic.

Illegal housing constitutes the most obvious example of the refusal of any such dichotomy. Whereas illegal housing, by definition, infringes upon formal legal rules, it became the norm for the popular majority in all metropolises under study - Beirut, Cairo, Damascus, Istanbul and Amman. It is less heuristic than ever, as we closely scrutinize this so-called illegality, to describe and analyze this quiet and steady production - with all its buildings and life investments - as partaking in a scheme opposing the formal and the informal or the legal and the illegal, and shaping two separate markets, real estate networks, and legal systems (cf. el Kadi, 1990). Similarly, the analysis from above, which considers the authoritarian State dominating its "non-citizens" which it controls in a patron-client relationship, while maintaining them within a no-law margin via illegal housing, falls short, whatever the importance of domination relations and the unfair use of force to back arbitrary decisions. Here again, denouncing unfairness cannot account for its operational modes; moreover, it radically erases what social practices are in terms of complexity, fluidity, order and (conflicting) negotiation and collaboration.

Let us go further with the example of law, around which many contributions to this volume revolve. The study of legal practices can follow different tracks. The theory of legal pluralism which puts forward the co-existence of multiple laws, beside State law, tended to be fashionable. Against the State presented as the sole producer of law, it sought to oppose the multiplicity of semi-autonomous and self-regulated social fields, themselves also producing legal rules. In this perspective, the State itself is nothing more than the aggregate of social fields. Whereas it is perfectly legitimate to posit the law and the State as objects of sociological analysis, the unlimited extension of the notion of law to any form of normativity seems excessive. Instead of the legal dichotomy between the monism of State law and the pluralism of non-State instances, we suggest a double shift in our viewpoint: on the one hand, it is necessary to analyze normative systems close to State law, in the sense that they are grounded on written or oral rules which a group of specific persons is deemed to know and interpret, they are endowed with instances (these very persons) in charge of their 
enforcement, and they are referred to by people as a legal system alternative to State law; on the other hand, it is also necessary to examine the ways in which people grasp their legal environment, understand it and act in that context, permanently confronting the plurality of reference social norms to the united character of the law in force. This is the challenge of the praxeological approach to law, which seeks to study, while faced to multiple customary systems, fluctuating legal practices and the impact of hegemonic State laws, the organizations and hierarchies designed in an endogenous manner by the people involved within a specific course of action. These organizations are necessarily neither institutionalized nor stable. Interaction contexts lead people to establish circumstantial hierarchies, to select priorities, and to proceed to what is conventionally called forum shopping. However, the same contexts can also compel them to act within one system rather than another and to have no choice about the competent instance, which nevertheless does not mean that they have no specific practice of these instances.

This praxeological approach to law asks how inhabitants produce their legality in practice: through the payment of taxes or fines which are used as means to warrant a right; through the use of seals, the Ministry of Finance's official forms; engineer documents; notary documents; evidences required by the cadastre department; or the use of "customary" contracts (very widespread in Jordan and Syria).

This volume collects contributions which share the refusal of dichotomies, to which they substitute the close observation of ordinary situations. Nothing contributes more to the understanding of how urban societies are produced than the detailed, not too interpretive, description of the ways in which housing deemed a priori illegal is secured, a transaction is concluded, a marking-out conflict is resolved, the breadth or the use of a street in construction is fixed and enforced, etc. And also the description of how a land-titling policy is conceived of, formerly recognized equipments are contested, a neighbourhood is equipped with electric wires, sewage, school facilities, asphalted roads, etc. The ambition of the volume is to restore the obvious continuum in the consolidation, building after building, of the popular neighbourhoods of the cities under study, while showing the proximity social relationships and the forms of solidarity which are mobilized.

Instead of looking for the Middle-East's specificities in politics, we suggest adopting a research policy scrutinizing the "proximate"; denying the holist and culturalist exception for the sake of the study of daily routines and practices. The first ambition is therefore to upgrade the knowledge of the urban land tenure dynamics, eventually underscoring the banality of current trends (something that can hardly be reconciled with the quest for something specifically characterizing the Middle-East taken as a whole).

We assumed that there is a tendency for these neighbourhoods to be reconsidered by the actors of urban politics - people responsible, agents of the government's offices, counsellors, international experts and development agencies. This tendency induces new relationships, new contexts of interaction between inhabitants and the actors of urban development, urbanism and taxation agencies. All these situations make more palatable (because they are more diverse and numerous) the possibilities of negotiation and adaptation involved in a complex and plural governance. This holds true for social science analysis, the methodological and epistemological renewing of which is closely connected to the dynamics of "real life" and has a direct impact on it (in a looping effect which is essential with regard to what was stated above). 
There is a momentum for the tacit acknowledgement of the positions which were acquired and of their regularisation, with a margin of uncertainty, while urban planning disappears in favour of the logic of juxtaposed projects and delegated urban development. The access to networks of urban services depends on criteria of profitability and on the inhabitants' financial capacity; networks no longer belong to the sovereign power of ministries and urban public agencies. In the same way, forced and massive dispossessions organized by the ruler tend to disappear, but "market evictions" (Lasserve, 2007) follow, which introduce a new land and tenure insecurity in the very place where land titling procedures seemed to guarantee stability (cf. J.F. Perouse's chapter).

The current convergence of urban land markets and the blurring of the line dividing the legal and the illegal lead us to consider the urban dynamics as less regulated and therefore uncertain and instable. They also lead us to consider the period that was dominated by public intervention, which gave way from the early 1990s to economic liberalization without political democracy, as a long "bracketing" of urban construction. Nowadays, the production of urban forms on the scale of plots, buildings, transactions, or even the more ambitious projects of developers, appears in a clearer and more assertive manner. Obviously, the evident liberalization of the "production forces" of the city facilitated our agreement on the way to observe those dynamics.

The issue of temporalities remain in the background since, clearly, the dynamics we observe are not new in any sense, whether in architecture, in popular urbanism or in legal regulations. The combinations which are described can be traced back to ways of building the city existing in the Middle-East since, at least, the Ottoman unification. It is an ordinary way of producing urban assemblages according to forms which are suitable, inherited and still active, according to what Bernard Lepetit (1993) called the "traces" of history.

\section{Dividing the volume into two parts: Why?}

This perspective is essential. The urban environment is not a neutral theatrical stage, but, through its geometric shapes and inhabited and invested forms, it is the existing condition of all the interactions that compose the city. The form, whether spatial, architectural, administrative or legal, is a constraint with which all the city's acting elements must come to terms. Therefore, the form is normative, not in the sense that it would be a causal factor, but in the sense that it conditions (cf. Wittgenstein, 1921; Petitot, 1985).

This is why we start with the study of ordinary forms and methods to build, to juxtapose and to compose buildings in the shape of streets and neighbourhoods. Panerai and Noweir's pioneering work on spatial and architectural shaping of popular neighbourhoods in Cairo is very important in that respect. In the same way, we also seek to describe grammars of normativity, either legal when practices articulate the formal rules and their local enforcement, or conventional when negotiation and compromise allow neighbours to adjust and adapt to one another.

Considering the normative conditions of daily practices related to land and tenure mobilization and thus of housing, neighbourhood shaping, transactions and conflict resolution in the urban thread, we offer a new reading of government action in and on the cities through case studies. These workings are understood as participating in the ongoing and negotiated reformulation of urban territories, emerging in precise contexts which deserve to be specified, and not as actions determining the unfolding of all the practices that take place downstream. 
The ordinary world which is put forward in our description endeavour refrains from any generalization and therefore allows us to assert the existence of a continuum which lacks in most studies on the issue of housing. Indeed, these studies remain frozen, because of their concern with reform, in the opposition between ordinary housing and State intervention. Customary law acquires a mythical status and becomes the reform's panacea to the predicament generated by positive law, among which generalized illegal housing (Lasserve, 2004), while, actually, such dichotomies exist in scholarly representations more than in ordinary practices. If our collective work contributes to something, it is to the renewing of the way of thinking about Arab urbanity (Dakhlia, 1998) that takes into consideration the forms of urban production, its configuration modes, the practices which underlie it and the norms which constrain it, in their ordinary accomplishment which, by far, bypasses the Arab world's borders.

\section{References} Press

Asef Bayat, 1997, Street Politics: Poor People's Movements in Iran, Columbia University

Isabelle Berry-Chikhaoui, Agnès Deboulet (eds.), 2000, Les compétences des citadins dans le Monde arabe: Penser, faire et transformer la ville, Tunis, Irmc, Paris, Karthala, Tours, Urbama, $406 \mathrm{p}$.

Jocelyne Dakhlia (ed.),1998, Urbanité arabe. Hommage à Bernard Lepetit, Sindbad-Actes Sud

Baudouin Dupret, 2006, Le jugement en action. Ethnométhodologie du droit, de la morale et de la justice en Égypte, Genève, Droz

Alain Durand-Lasserve A., 2007, «Market-driven eviction processes in developing country cities: the cases of Kigali in Rwanda and Phnong Penh in Cambodia ». Global Urban Development, Volume 3, Issue 1; http://www.globalurban.org/GUDMag07Vol3Iss1/DurandLasserve\%20PDF.pdf

Alain Durand-Lasserve A., 2004, « La gestion foncière néo-coutumière dans les pays d'Afrique sub-saharienne », in Goldblum Ch., Osmont A., Diaz I. (coord.), Gouverner les villes du Sud. Défis pour la recherche et pour l'action, Actes du colloque international du PRUD (Programme de la Recherche Urbaine pour le Développement), Paris, Unesco

El Kadi, G. 1990. «L'articulation des deux circuits de la gestion foncière en Egypte : le cas du Caire ». In P. Amis and P. Lloyd, eds., Housing Africa's Urban Poor. Manchester University Press, Manchester, pp. 103-122.

Homa Hoodfar, 1997, Between Marriage and the Market. Intimate Politics and Survival in Cairo, University of California Press

Bernard Lepetit, 1993, «Une herméneutique urbaine est-elle possible ? », in Bernard Lepetit et Denise Pumain (coordonné par), Temporalités urbaines, Paris, Anthropos, 1993, pp. 287-299.

Philippe Panerai et Sawsan Noweir, « Du rural à l'urbain » Égypte/Monde arabe, Première série, 1, 1990, [En ligne], mis en ligne le 08 juillet 2008. URL : http://ema.revues.org/index 182.html. Consulté le 14 août 2008

Nezar AlSayyad, 1993, «Informal housing in a comparative perspective: On Squatting, Culture, and Development in a Latin American and a Middle Eastern Context », Review of Urban \& Regional Development Studies, vol. 5, n 1 pp. 3-18

Diane Singerman, 1996, Avenues of Participation: Family, Politics, and Networks in Urban Quarters of Cairo, Princeton University Press

Jean Petitot, 1985, Morphogenèse du Sens, PUF

Ludwig Wittgenstein, 2001 (1921), Tractatus logico-philosophicus, Gallimard 


\section{CONTENTS}

Introduction

\section{Part 1 - The Production of Forms and Norms from within}

1. Etienne Lena

The mukhalafat of Damas, a case study.

2. Baudouin Dupret \& Myriam Ferrier

Selling one's property in an informal settlement: a case study in Damascus

3. Myriam Ferrier, Paying taxes: a way to secure one's property in an informal settlement of Damascus

4. Marion Séjourné

Inhabitants' daily practices and strategies to obtain legality of their home and mechanisms to secure their tenure (Egypt)

5. Franziska Laue \& Marieke Boller

Vertical versus Horizontal: Constraints of modern living conditions in informal settlements and the reality of construction

6. Agnès Deboulet

Cooperation and pragmatism: shifting theories and practices about legal claims and urban rights recognition

7. Ward Vloeberghs

The Genesis of a Mosque: Negotiating Sacred Space in Downtown Beirut

Part 2 - Public Policies toward Informal Settlements: From Eviction to Self-help Recognition (or Legitimation), and back

8. Myriam Ababsa

Public policies toward informal settlements in Jordan (1965- 2007)

9. Eric Denis

The commodification of ashwayyiat(s) in Cairo: De Soto unifying the real estate market

10. Jean-François Pérouse

Mülk Allahindir ("This house is God's property"): Legitimizing the land property in the suburbs of Istanbul

11. Diana Dumour

Wadi Abdoun : From slums to towers. The upgrading policy of an informal settlement in Amman, Jordan

12. Fabrice Balanche

Illegal housing in Damascus

13. Valérie Clerc

Laws and Rights in a Great Urban Project Toward Irregular Settlements in Beirut

14. Falk Jaehnigen

The Coastal Settlements of Ouzaii and Jnah. Analysis for an upgrading project in Beirut 